\title{
PENGGUNAAN MODEL PEMBELAJARAN CONTEXTUAL TEACHING AND LEARNING MENINGKATKAN KETERAMPILAN PASSING BOLA BASKET PADA MATA PELAJARAN PENJAS ORKES KELAS IX MTS NEGERI 1 KOTA SERANG
}

\author{
Ahpudin \\ Madrasah Tsanawiyah Negeri 1 Kota Serang \\ e-mail:ahpudin71@gmail.com
}

\begin{abstract}
This research was conducted in class IX G MTs Negeri 1 Kota Serang with 28 students, nine male students, and 19 female students in the 1st semester of the 2015-2016 academic year. The stages are planning, implementing, observing, and reflecting in each cycle, and this research was completed in two cycles. The research data obtained through observations by researchers is data on the results of learning the skills of passing big ball games obtained through performance from the psychomotor domain. Data analysis in this study used descriptive analysis using percentage techniques to see trends that occur in learning activities. This study aims to determine the effectiveness of the Contextual Teaching and Learning learning model in improving basketball passing skills in the IX class of Penjas Orkes subjects at MTs Negeri 1 Kota Serang semester 1 of the 2015-2016 academic year. Based on the results of this study, it can be concluded that the Contextual Teaching and Learning learning model can improve basketball passing skills in the IX class of Penjas Orkes subjects at MTs Negeri 1 Kota Serang in the 2015-2016 academic year, where learning outcomes in the initial conditions are $67.86 \%$ or 19 students, at the end of the first cycle it became $78.57 \%$ or 22 students. Atat the end of the second cycle, it became $92.86 \%$ or 26 students.
\end{abstract}

Keywords: activity; basketball; contextual teaching and learning; skills.

\begin{abstract}
Abstrak
Penelitian ini dilaksanakan di kelas IX G MTs Negeri 1 Kota Serang dengan siswa berjumlah 28 siswa, 9 siswa laki-laki dan 19 siswa perempuan pada semester 1 Tahun Pelajaran 2015-2016. Adapun tahapan - tahapannya yaitu perencanaan, pelaksanaan, observasi, dan refleksi dalam setiap siklus dan penelitian ini selesai pada dua siklus. Data penelitian ini diperoleh melalui pengamatan oleh peneliti merupakan data hasil belajar keterampilan passing permainan bola besar yang diperoleh melalui unjuk kerja dari ranah psikomotorik. Analisis data dalam penelitian ini menggunakan analisis secara deskriptif dengan menggunakan teknik persentase untuk melihat kecenderungan yang terjadi dalam kegiatan pembelajaran. Penelitian ini bertujuan untuk mengetahui efektifitas model pembelajaran Contextual Teaching and Learning dalam meningkatkan keterampilan passing bola basket pada mata pelajaran Penjas Orkes kelas IX di MTs Negeri 1 Kota Serang semester 1 tahun pelajaran 2015-2016. Berdasarkan hasil penelitian ini dapat disimpulkan bahwa model pembelajaran Contextual Teaching and Learning dapat meningkatkan keterampilan passing bola basket pada mata pelajaran Penjas Orkes kelas IX di MTs Negeri 1 Kota Serang Tahun Pelajaran 2015-2016, dimana hasil belajar pada kondisi awal 67,86\% atau 19 siswa, pada akhir siklus I menjadi 78,57\% atau 22 siswa dan pada akhir siklus II menjadi 92,86\% atau 26 siswa.
\end{abstract}

Kata Kunci: aktivitas; bola basket; contextual teaching and learning; keterampilan. 


\section{PENDAHULUAN}

Proses pembelajaran merupakan salah satu faktor penentu keberhasilan kegiatan pembelajaran. Hal ini harus dirancang dan disesuaikan antara tujuan, proses, serta hasil belajar siswa, baik secara individu maupun kelompok. Dalam mempersiapkan serta merancang suatu proses pembelajaran perlu melihat dan mempertimbangkan kemampuan siswa, hal tersebut seperti dijelaskan oleh Gagne yang dikutip oleh Dimyati dan Mudjiono (2009:10) yaitu: “Belajar ada tiga komponen penting yaitu kondisi eksternal, kondisi internal, dan hasil belajar". Keadaan kemampuan siswa tersebut dapat diwujudkan dalam bentuk keterampilan gerak di mana suatu kemampuan siswa yang berhubungan dengan proses pembelajaran yang relatif kurang maksimal. Komponen yang termasuk didalamnya adalah kurangnya pengalaman gerak, kurang bersemangat, gerak yang asal-asalan sehingga akan berpengaruh terhadap penguasaan keterampilan siswa.

Pembelajaran Pendidikan Jasmani Olahraga dan Kesehatan sebagai suatu proses merupakan sarana untuk mengembangkan aspek kognitif, afektif dan psikomotorik secara utuh dengan mengutamakan proses pengembangan keterampilan siswa (Yuniartik, Hidayah, \& Nasuka, 2017). Oleh karena itu guru dituntut untuk memberikan proses pengalaman gerak yang mampu mengembangkan keterampilan siswa secara optimal.

Bola basket adalah olahraga berkelompok yang terdiri atas dua tim beranggotakan masing-masing lima orang yang saling bertanding mencetak poin dengan memasukkan bola ke dalam keranjang lawan. Pada prinsipnya permainan bola basket dapat dimainkan oleh setiap orang, baik anak-anak, remaja, orang dewasa, maupun orang tua yang usianya diatas lima puluh tahun. Terdapat beberapa teknik dasar permainan bola basket diantaranya mengoper bola atau passing, menggiring bola, dan menembak. Mengoper atau melempar bola terdiri atas tiga cara yaitu, melempar bola dari depan dada (chest pass) yang dilakukan dari dada ke dada dengan cepat dalam permainan, melempar bola memantul ke tanah atau lantai (bounce pass), dan melempar bola dari atas kepala (over head pass).

Cara memegang bola basket adalah sikap tangan membentuk mangkuk besar. Bola berada di antara kedua telapak tangan. Telapak tangan melekat di samping bola agak ke belakang, jari-jari terentang melekat pada bola. Ibu jari terletak dekat dengan badan dibagian belakang bola yang menghadap ke arah tengah depan. Kedua kaki membentuk kudakuda dengan salah satu kaki di depan. Badan sedikit condong ke depan dan lutut rileks.

Keterampilan passing sebagai salah satu kemampuan dasar yang harus dimiliki oleh masing-masing siswa yang dimungkinkan akan mempengaruhi dalam proses pembelajaran permainan bola basket. Hal tersebut diyakini oleh guru untuk menggambarkan kemampuan kreativitas siswa secara umum, serta dapat menggambarkan keberhasilan proses pembelajaran. Dengan demikian akan membantu keberhasilan pembelajaran yang selama ini masih dirasakan kurang. Salah satu upaya guru dalam mengatasi kurangnya 
Wawasan:

Jurnal Kediklatan Balai Diklat Keagamaan Jakarta PISSN: 2548-9232; ${ }_{\mathrm{E}}$ ISSN: 2775-3573

Volume 2 Nomor 1 Tahun 2021: 49-63

keterampilan passing dalam permainan bola basket maka guru harus menampilkan berbagai model pembelajaran yang menarik yaitu dengan Contextual Teaching and Learning.

Dalam mengatasi kurangnya kreativitas siswa, guru harus mampu memberikan proses pembelajaran yang menarik sehingga menjadikan situasi dan kondisi learning by doing bagi siswa. Guna mewujudkan hal tersebut, maka guru harus dapat memberikan pengalaman gerak pada siswa yang seluas-luasnya sehingga usaha pencapaian pembelajaran dengan memperhatikan karakteristik, tujuan, dan materi pembelajaran. Guru harus mampu menyesuaikan ketiga unsur tersebut yang menjadi satu kesatuan yang sinergis dalam upaya mencapai proses pembelajaran pada keterampilan passing dalam permainan bola basket.

Untuk mengatasi kelemahan kelemahan diantaranya siswa kurang kreatif, ketergantungan dengan contoh guru,siswa kurang antusias untuk mencoba maka peneliti akan mencoba menggunakan model pembelajaran kontekstual atau lebih dikenal dengan Contextual Teaching and Learning (CTL). CTL merupakan konsep pembelajaran yang aktual dan bias dikembangkan diberbagai lembaga pendidikan. Dengan demikian, jelaslah bahwa seorang guru hendaknya mampu menerapkan model pembelajaran yang tepat agar kegiatan pembelajaran berjalan lebih menarik dan menyenangkan bagi siswa.

Berdasarkan uraian diatas, maka penulis akan mencoba meneliti "Penggunaan Model Pembelajaran Contextual Teaching and Learning
Meningkatkan Keterampilan Passing Bola Basket pada Mata Pelajaran Penjas Orkes Kelas IX Di MTs Negeri 1 Kota Serang Tahun 2015".

\section{METODE}

Jenis penelitian yang digunakan adalah Penelitian Tindakan Kelas (PTK). Setiap tindakan upaya pencapaian tujuan tersebut dirancang dalam satu unit sebagai siklus. Penelitian ini bertujuan untuk memperoleh data tentang "Penggunaan Model Pembelajaran Contextual Teaching and Learning dapat Meningkatkan Keterampilan Passing Bola Basket pada Mata Pelajaran Penjas Orkes Kelas IX di MTs Negeri 1 Kota Serang Tahun 2015". baik dari segi kognitif, afektif maupun psikomotorik dalam proses pembelajaran. Namun dalam penelitian ini berfokus pada aspek psikomotorik atau keterampilan.

Pelaksanaan Penelitian Tindakan Kelas ini dilakukan di MTs Negeri 1 Kota Serang yang beralamat di Jalan Bhayangkara No. 84 Kelurahan Sumur Pecung Kecamatan Serang Kota, Kota Serang Provinsi Banten. Adapun pelaksanaannya pada semester ganjil tahun pelajaran 2015-2016. Penelitian Tindakan Kelas ini membutuhkan waktu 2 bulan yang dilaksanakan dari mulai tanggal 19 Agustus sampai dengan 23 September 2015 sebanyak 4 pertemuan tatap muka dalam kegiatan pembelajaran termasuk Pra Siklus. Adapun kelas yang dijadikan objek yaitu kelas IXG Tahun Pelajaran 20152016 sebanyak 28 siswa yang terdiri dari: 9 orang putra dan 19 orang putri. 
Wawasan:

Jurnal Kediklatan Balai Diklat Keagamaan Jakarta PISSN: 2548-9232; EISSN: 2775-3573

Volume 2 Nomor 1 Tahun 2021: 49-63

\section{HASIL DAN PEMBAHASAN}

Hasil belajar keterampilan passing bola basket meliputi tiga ranah yaitu ranah kognitif yang dinilai melalui tes tulis, ranah afektif diperoleh melalui pengamatan sikap siswa saat pembelajaran berlangsung, dan ranah psikomotor yang dinilai dari unjuk kerja keterampilan passing bola basket.

\section{Data Pra Siklus}

Kondisi awal siswa kelas IX G MTsN 1 Kota Serang Tahun Pelajaran 2015/2016 sebelum diberi tindakan penerapan model pembelajaran Contextual Teaching and Learning dengan batas kelulusan minimal (KKM) 75 sebagai berikut:

Tabel 1 Hasil Belajar Sebelum Tindakan (Pra Siklus)

\begin{tabular}{|c|c|c|c|}
\hline Responden & Nilai & Deskripsi & Ket \\
\hline 1 & 75 & $\begin{array}{l}\text { Posisi } \\
\text { badan, } \\
\text { sikap } \\
\text { tangan dan } \\
\text { lemparan } \\
\text { bola cukup } \\
\text { baik }\end{array}$ & Tuntas \\
\hline 2 & 73 & $\begin{array}{l}\text { Baru } \\
\text { menguasai } \\
\text { posisi } \\
\text { badan dan } \\
\text { sikap } \\
\text { tangan, } \\
\text { perkenaan } \\
\text { bola } \\
\text { kurang }\end{array}$ & $\begin{array}{c}\text { Tidak } \\
\text { Tuntas }\end{array}$ \\
\hline 3 & 70 & $\begin{array}{l}\text { Masih } \\
\text { kurang } \\
\text { dalam } \\
\text { penguasaan } \\
\text { passing }\end{array}$ & $\begin{array}{c}\text { Tidak } \\
\text { Tuntas }\end{array}$ \\
\hline 4 & 78 & $\begin{array}{l}\text { Mampu } \\
\text { melakukan } \\
\text { teknik } \\
\text { passing }\end{array}$ & Tuntas \\
\hline 5 & 78 & Mampu & Tuntas \\
\hline
\end{tabular}

\begin{tabular}{|c|c|c|c|}
\hline & & $\begin{array}{l}\text { melakukan } \\
\text { teknik } \\
\text { passing }\end{array}$ & \\
\hline 6 & 75 & $\begin{array}{l}\text { Posisi } \\
\text { badan, } \\
\text { sikap } \\
\text { tangan dan } \\
\text { lemparan } \\
\text { bola cukup } \\
\text { baik }\end{array}$ & Tuntas \\
\hline 7 & 73 & $\begin{array}{l}\text { Baru } \\
\text { menguasai } \\
\text { posisi } \\
\text { badan dan } \\
\text { sikap } \\
\text { tangan, } \\
\text { perkenaan } \\
\text { bola } \\
\text { kurang }\end{array}$ & $\begin{array}{l}\text { Tidak } \\
\text { Tuntas }\end{array}$ \\
\hline 8 & 75 & $\begin{array}{l}\text { Posisi } \\
\text { badan, } \\
\text { sikap } \\
\text { tangan dan } \\
\text { lemparan } \\
\text { bola cukup } \\
\text { baik }\end{array}$ & Tuntas \\
\hline 9 & 75 & $\begin{array}{l}\text { Posisi } \\
\text { badan, } \\
\text { sikap } \\
\text { tangan dan } \\
\text { lemparan } \\
\text { bola cukup } \\
\text { baik }\end{array}$ & Tuntas \\
\hline 10 & 73 & $\begin{array}{l}\text { Baru } \\
\text { menguasai } \\
\text { posisi } \\
\text { badan dan } \\
\text { sikap } \\
\text { tangan, } \\
\text { perkenaan } \\
\text { bola } \\
\text { kurang } \\
\end{array}$ & $\begin{array}{c}\text { Tidak } \\
\text { Tuntas }\end{array}$ \\
\hline 11 & 78 & $\begin{array}{l}\text { Mampu } \\
\text { melakukan } \\
\text { teknik } \\
\text { passing }\end{array}$ & Tuntas \\
\hline 12 & 73 & $\begin{array}{l}\text { Baru } \\
\text { menguasai } \\
\text { posisi } \\
\text { badan dan } \\
\text { sikap } \\
\text { tangan, } \\
\text { perkenaan }\end{array}$ & $\begin{array}{l}\text { Tidak } \\
\text { Tuntas }\end{array}$ \\
\hline
\end{tabular}


Wawasan:

Jurnal Kediklatan Balai Diklat Keagamaan Jakarta

PISSN: 2548-9232; ${ }_{\mathrm{E}}$ ISSN: 2775-3573

Volume 2 Nomor 1 Tahun 2021: 49-63

\begin{tabular}{|c|c|c|c|}
\hline & & $\begin{array}{l}\text { bola } \\
\text { kurang }\end{array}$ & \\
\hline 13 & 70 & $\begin{array}{l}\text { Masih } \\
\text { kurang } \\
\text { dalam } \\
\text { penguasaan } \\
\text { passing }\end{array}$ & $\begin{array}{l}\text { Tidak } \\
\text { Tuntas }\end{array}$ \\
\hline 14 & 75 & $\begin{array}{l}\text { Posisi } \\
\text { badan, } \\
\text { sikap } \\
\text { tangan dan } \\
\text { lemparan } \\
\text { bola cukup } \\
\text { baik }\end{array}$ & Tuntas \\
\hline 15 & 75 & $\begin{array}{l}\text { Posisi } \\
\text { badan, } \\
\text { sikap } \\
\text { tangan dan } \\
\text { lemparan } \\
\text { bola cukup } \\
\text { baik }\end{array}$ & Tuntas \\
\hline 16 & 80 & $\begin{array}{l}\text { Mampu } \\
\text { melakukan } \\
\text { passing } \\
\text { dengan } \\
\text { baik }\end{array}$ & Tuntas \\
\hline 17 & 78 & $\begin{array}{l}\text { Mampu } \\
\text { melakukan } \\
\text { teknik } \\
\text { passing }\end{array}$ & Tuntas \\
\hline 18 & 75 & $\begin{array}{l}\text { Posisi } \\
\text { badan, } \\
\text { sikap } \\
\text { tangan dan } \\
\text { lemparan } \\
\text { bola cukup } \\
\text { baik }\end{array}$ & Tuntas \\
\hline 19 & 75 & $\begin{array}{l}\text { Posisi } \\
\text { badan, } \\
\text { sikap } \\
\text { tangan dan } \\
\text { lemparan } \\
\text { bola cukup } \\
\text { baik }\end{array}$ & Tuntas \\
\hline 20 & 75 & $\begin{array}{l}\text { Posisi } \\
\text { badan, } \\
\text { sikap } \\
\text { tangan dan } \\
\text { lemparan } \\
\text { bola cukup } \\
\text { baik }\end{array}$ & Tuntas \\
\hline 21 & 75 & $\begin{array}{l}\text { Posisi } \\
\text { badan, }\end{array}$ & Tuntas \\
\hline
\end{tabular}

\begin{tabular}{|c|c|c|c|}
\hline & & $\begin{array}{l}\text { sikap } \\
\text { tangan dan } \\
\text { lemparan } \\
\text { bola cukup } \\
\text { baik }\end{array}$ & \\
\hline 22 & 70 & $\begin{array}{l}\text { Masih } \\
\text { kurang } \\
\text { dalam } \\
\text { penguasaan } \\
\text { passing }\end{array}$ & $\begin{array}{c}\text { Tidak } \\
\text { Tuntas }\end{array}$ \\
\hline 23 & 75 & $\begin{array}{l}\text { Posisi } \\
\text { badan, } \\
\text { sikap } \\
\text { tangan dan } \\
\text { lemparan } \\
\text { bola cukup } \\
\text { baik }\end{array}$ & Tuntas \\
\hline 24 & 70 & $\begin{array}{l}\text { Masih } \\
\text { kurang } \\
\text { dalam } \\
\text { penguasaan } \\
\text { passing }\end{array}$ & $\begin{array}{c}\text { Tidak } \\
\text { Tuntas }\end{array}$ \\
\hline 25 & 75 & $\begin{array}{l}\text { Posisi } \\
\text { badan, } \\
\text { sikap } \\
\text { tangan dan } \\
\text { lemparan } \\
\text { bola cukup } \\
\text { baik }\end{array}$ & Tuntas \\
\hline 26 & 70 & $\begin{array}{l}\text { Masih } \\
\text { kurang } \\
\text { dalam } \\
\text { penguasaan } \\
\text { passing }\end{array}$ & $\begin{array}{c}\text { Tidak } \\
\text { Tuntas }\end{array}$ \\
\hline 27 & 80 & $\begin{array}{l}\text { Mampu } \\
\text { melakukan } \\
\text { passing } \\
\text { dengan } \\
\text { baik }\end{array}$ & Tuntas \\
\hline 28 & 80 & $\begin{array}{l}\text { Mampu } \\
\text { melakukan } \\
\text { passing } \\
\text { dengan } \\
\text { baik }\end{array}$ & Tuntas \\
\hline Jumlah & 2094 & & \\
\hline Rata-rata & 74,79 & & \\
\hline
\end{tabular}

Berikut hasil kegiatan pembelajaran sebelum tindakan (Pra Siklus) dalam persentase ketuntasan minimal: 
Wawasan:

Jurnal Kediklatan Balai Diklat Keagamaan Jakarta PISSN: 2548-9232; EISSN: 2775-3573

Volume 2 Nomor 1 Tahun 2021: 49-63

Tabel 2 Hasil Belajar Siswa dalam Keterampilan Passing Bola Basket Sebelum Tindakan (Pra Siklus)

\begin{tabular}{lccc}
\hline \multirow{2}{*}{ Penilaian } & \multicolumn{2}{c}{$\begin{array}{c}\text { Kondisi Awal (Pra } \\
\text { Siklus) }\end{array}$} & Ket \\
\cline { 2 - 4 } & Persentase & $\begin{array}{c}\text { Jml } \\
\text { Siswa }\end{array}$ \\
\hline Hasil & $67,86 \%$ & 19 & Tuntas \\
Balajar & $32,14 \%$ & 9 & Belum \\
Passing & & & Tuntas \\
Bola & & & \\
Basket & & & \\
\hline
\end{tabular}

\section{Data Siklus I}

\section{Siklus 1 Pertemuan 1}

a. Perencanaan Tindakan

Pada tahap perencanaan ini guru sebagai peneliti menyusun skenario pembelajaran yang terdiri dari:

(1) peneliti melakukan analisis kurikulum untuk mengetahui kompetensi dasar yang akan disampaikan siswa dalam pembelajaran Penjas Orkes.

(2) membuat rencana pembelajaran dengan mengacu pada tindakan yang diterapkan dalam PTK, yaitu pembelajaran keterampilan passing bola basket.

(3) menyusun instrumen yang digunakan dalam siklus PTK.

(4) menyusun alat evaluasi pembelajaran.

b. Tahap Pelaksanaan

Pada tahap pelaksanaan, kegiatan yang akan dilakukan adalah melaksanakan proses pembelajaran di lapangan dengan langkah-langkah kegiatan antara lain:

(1) Menjelaskan kegiatan belajar mengajar keterampilan passing bola basket.
(2) Melakukan pemanasan.

(3) Memainkan teknik dasar passing bola basket.

(4) Membentuk kelompok dalam proses pembelajaran.

(5) Melakukan pembelajaran teknik dan passing bola basket dengan menggunakan permainan.

(6) Menarik kesimpulan pembelajaran.

(7) Penilaian dilaksanakan selama proses pembelajaran berlangsung.

(8) Melakukan pendinginan.

c. Pengamatan Tindakan

Pengamatan dilakukan bertahap:

(1) Peningkatan hasil belajar siswa dalam pembelajaran.

(2) Aktivitas siswa selama pembelajaran berlangsung.

d. Tahap Evaluasi (Refleksi)

Refleksi merupakan uraian tentang prosedur analisis terhadap hasil penelitian dan refleksi yang berkaitan dengan proses dan dampak tindakan perbaikan yang dilaksanakan serta kriteria dan rencana bagi siklus tindakan berikutnya.

\section{Siklus I Pertemuan 2}

\section{a. Perencanaan Tindakan}

Berdasarkan dari analisis dan refleksi pada pertemuan pertama, maka perencanaan tindakan berikutnya adalah sebagai berikut:

(1) Guru sebagai peneliti bersama-sama membuat Rencana Pelaksanaan Pembelajaran (RPP) dengan mengacu pada tindakan (treatment) yang diterapkan 
Wawasan:

Jurnal Kediklatan Balai Diklat Keagamaan Jakarta PISSN: 2548-9232; EISSN: 2775-3573

Volume 2 Nomor 1 Tahun 2021: 49-63

dalam PTK, $\begin{array}{r}\text { yaitu } \\ \text { model } \\ \text { menerapkan } \\ \text { pembelajaran }\end{array}$
Teaching and Learning untuk
meningkatkan keterampilan
passing bola basket dengan
tingkat kesulitan yang
meningkat.

(2) Menyiapkan alat yang digunakan dalam permainan untuk membantu pembelajaran dan menyiapkan formasi penataan alat yang lebih menarik lagi.

(3) Menyusun lembar observasi atau pengamatan pembelajaran.

b. Tahap pelaksanaan

Pada tahap pelaksanaan, kegiatan yang akan dilakukan adalah melaksanakan proses pembelajaran di lapangan dengan langkah-langkah kegiatan antara lain:

(1) Menjelaskan kegiatan belajar mengajar tentang keterampilan passing dalam sepak bola.

(2) Melakukan pemanasan.

(3) Memainkan permainan keterampilan passing sepak bola.

(4) Membentuk kelompok dalam proses pembelajaran.

(5) Melakukan pembelajaran keterampilan passing bola basket dengan menggunakan permainan.

(6) Menarik kesimpulan pembelajaran dan memberikan rekognisi atau penghargaan bagi siswa yang dapat menampilkan keterampilan terbaik.
(7) Penilaian dilaksanakan selama proses pembelajaran berlangsung.

(8) Melakukan pendinginan dan follow up.

(9) Berdoa dan membubarkan barisan

c. Observasi Tindakan

Pengamatan dilakukan oleh guru sebagai peneliti yang berkolaborasi saat proses pembelajaran berlangsung. Pengamatan dilakukan menggunakan lembar observasi dan lembar penilaian terhadap kemampuan keterampilan passing bola basket siswa selama mengikuti proses kegiatan pembelajaran. Hasil observasi tersebut adalah:

1. Proses Tindakan

2. Pengaruh Tindakan

3. Kendala dalam Implementasi Tindakan

4. Identifikasi Penyebab Tindakan

5. Persoalan lain yang timbul

d. Refleksi Tindakan

Berdasarkan hasil observasi pada tindakan kedua tersebut, peneliti melakukan analisis dan refleksi sebagai berikut:

1. Siklus I pertemuan ke-2, indikator yang tercantum dalam RPP juga belum sepenuhnya tercapai. Namun ada peningkatan yang lebih baik lagi. Pada pertemuan ini ada 3 siswa yang semula belum tuntas mampu mencapai batas KKM.

2. Pelaksanaan proses belajar mengajar telah sesuai dengan 
Wawasan:

Jurnal Kediklatan Balai Diklat Keagamaan Jakarta PISSN: 2548-9232; ${ }_{\mathrm{E}}$ ISSN: 2775-3573

Volume 2 Nomor 1 Tahun 2021: 49-63

rencana yang telah dibuat dalam Rencana Pelaksanaan Pembelajaran (RPP).

3. Agar tidak mengganggu konsentrasi siswa, guru harus bisa memberikan suasana kondusif pada saat proses belajar mengajar berlangsung. Mengondisikan siswa untuk tidak terpengaruh dengan teman dari kelas lain. Salah satu caranya adalah dengan membuat suasana pembelajaran lebih menyenangkan.

4. Guru harus selalu memantau, mengingatkan siswa dan menegur siswa yang tidak memperhatikan pelajaran atau siswa yang sedang berteduh dan duduk di pinggir lapangan.

5. Hasil dari rekap nilai psikomotor, afektif dan kognitif sudah menunjukkan peningkatan yang baik. Dari data tersebut dapat dihitung bahwa target capaian pada siklus I sudah terpenuhi.

Tabel 3 Hasil Belajar Siklus I

\begin{tabular}{|c|c|c|c|}
\hline Responden & Nilai & Deskripsi & Ket \\
\hline 1 & 78 & $\begin{array}{l}\text { Mampu } \\
\text { melakukan } \\
\text { teknik } \\
\text { passing }\end{array}$ & Tuntas \\
\hline 2 & 75 & $\begin{array}{l}\text { Posisi badan, } \\
\text { sikap tangan } \\
\text { dan } \\
\text { lemparan } \\
\text { bola cukup } \\
\text { baik }\end{array}$ & Tuntas \\
\hline 3 & 73 & $\begin{array}{l}\text { Baru } \\
\text { menguasai } \\
\text { posisi badan } \\
\text { dan sikap }\end{array}$ & $\begin{array}{c}\text { Tidak } \\
\text { Tuntas }\end{array}$ \\
\hline
\end{tabular}

\begin{tabular}{|c|c|c|c|}
\hline & & $\begin{array}{l}\text { tangan, } \\
\text { perkenaan } \\
\text { bola kurang }\end{array}$ & \\
\hline 4 & 80 & $\begin{array}{l}\text { Mampu } \\
\text { melakukan } \\
\text { passing } \\
\text { dengan baik }\end{array}$ & Tuntas \\
\hline 5 & 85 & $\begin{array}{l}\text { Mahir dalam } \\
\text { melakukan } \\
\text { passing }\end{array}$ & Tuntas \\
\hline 6 & 78 & $\begin{array}{l}\text { Mampu } \\
\text { melakukan } \\
\text { teknik } \\
\text { passing }\end{array}$ & Tuntas \\
\hline 7 & 75 & $\begin{array}{l}\text { Posisi badan, } \\
\text { sikap tangan } \\
\text { dan } \\
\text { lemparan } \\
\text { bola cukup } \\
\text { baik }\end{array}$ & Tuntas \\
\hline 8 & 80 & $\begin{array}{l}\text { Mampu } \\
\text { melakukan } \\
\text { passing } \\
\text { dengan baik }\end{array}$ & Tuntas \\
\hline 9 & 78 & $\begin{array}{l}\text { Mampu } \\
\text { melakukan } \\
\text { teknik } \\
\text { passing }\end{array}$ & Tuntas \\
\hline 10 & 73 & $\begin{array}{l}\text { Baru } \\
\text { menguasai } \\
\text { posisi badan } \\
\text { dan sikap } \\
\text { tangan, } \\
\text { perkenaan } \\
\text { bola kurang }\end{array}$ & $\begin{array}{c}\text { Tidak } \\
\text { Tuntas }\end{array}$ \\
\hline 11 & 83 & $\begin{array}{l}\text { Mampu } \\
\text { melakukan } \\
\text { passing } \\
\text { sesuai teknik } \\
\text { yang baik }\end{array}$ & Tuntas \\
\hline 12 & 80 & $\begin{array}{l}\text { Mampu } \\
\text { melakukan } \\
\text { passing } \\
\text { dengan baik }\end{array}$ & Tuntas \\
\hline 13 & 73 & $\begin{array}{l}\text { Baru } \\
\text { menguasai } \\
\text { posisi badan } \\
\text { dan sikap } \\
\text { tangan, }\end{array}$ & $\begin{array}{c}\text { Tidak } \\
\text { Tuntas }\end{array}$ \\
\hline
\end{tabular}


Wawasan:

Jurnal Kediklatan Balai Diklat Keagamaan Jakarta

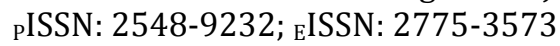

Volume 2 Nomor 1 Tahun 2021: 49-63

\begin{tabular}{|c|c|c|c|}
\hline & & $\begin{array}{l}\text { perkenaan } \\
\text { bola kurang }\end{array}$ & \\
\hline 14 & 78 & $\begin{array}{l}\text { Mampu } \\
\text { melakukan } \\
\text { teknik } \\
\text { passing }\end{array}$ & Tuntas \\
\hline 15 & 80 & $\begin{array}{l}\text { Mampu } \\
\text { melakukan } \\
\text { passing } \\
\text { dengan baik }\end{array}$ & Tuntas \\
\hline 16 & 85 & $\begin{array}{l}\text { Mahir dalam } \\
\text { melakukan } \\
\text { passing }\end{array}$ & Tuntas \\
\hline 17 & 80 & $\begin{array}{l}\text { Mampu } \\
\text { melakukan } \\
\text { passing } \\
\text { dengan baik }\end{array}$ & Tuntas \\
\hline 18 & 80 & $\begin{array}{l}\text { Mampu } \\
\text { melakukan } \\
\text { passing } \\
\text { dengan baik }\end{array}$ & Tuntas \\
\hline 19 & 83 & $\begin{array}{l}\text { Mampu } \\
\text { melakukan } \\
\text { passing } \\
\text { sesuai teknik } \\
\text { yang baik }\end{array}$ & Tuntas \\
\hline 20 & 78 & $\begin{array}{l}\text { Mampu } \\
\text { melakukan } \\
\text { teknik } \\
\text { passing }\end{array}$ & Tuntas \\
\hline 21 & 80 & $\begin{array}{l}\text { Mampu } \\
\text { melakukan } \\
\text { passing } \\
\text { dengan baik }\end{array}$ & Tuntas \\
\hline 22 & 73 & $\begin{array}{l}\text { Baru } \\
\text { menguasai } \\
\text { posisi badan } \\
\text { dan sikap } \\
\text { tangan, } \\
\text { perkenaan } \\
\text { bola kurang }\end{array}$ & $\begin{array}{l}\text { Tidak } \\
\text { Tuntas }\end{array}$ \\
\hline 23 & 80 & $\begin{array}{l}\text { Mampu } \\
\text { melakukan } \\
\text { passing } \\
\text { dengan baik }\end{array}$ & Tuntas \\
\hline 24 & 73 & $\begin{array}{l}\text { Baru } \\
\text { menguasai } \\
\text { posisi badan } \\
\text { dan sikap }\end{array}$ & $\begin{array}{l}\text { Tidak } \\
\text { Tuntas }\end{array}$ \\
\hline
\end{tabular}

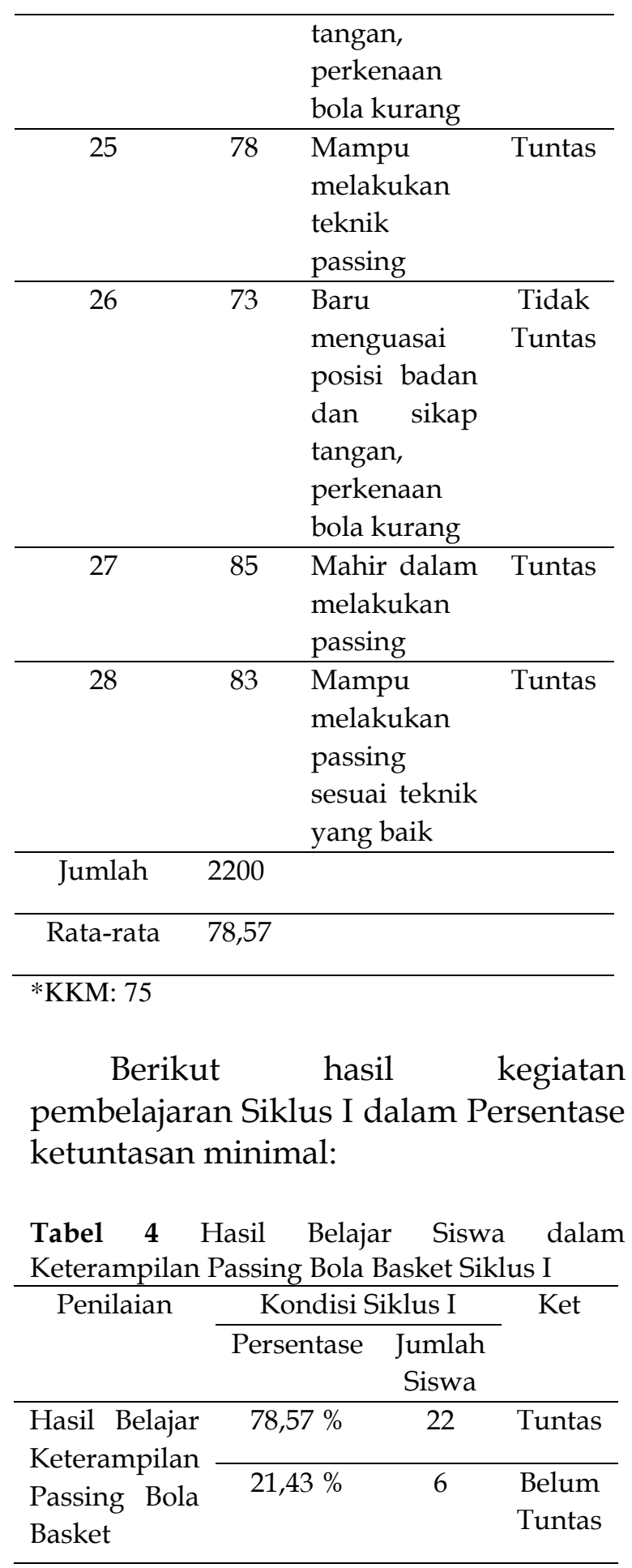

\section{Data Siklus II \\ Siklus II Pertemuan 1}
a. Perencanaan Tindakan
Perencanaan Tindakan sebagai berikut:


Wawasan:

Jurnal Kediklatan Balai Diklat Keagamaan Jakarta PISSN: 2548-9232; ${ }_{\mathrm{E}}$ ISSN: 2775-3573

Volume 2 Nomor 1 Tahun 2021: 49-63

(1) Guru sebagai peneliti berkolaborasi membuat Rencana Pelaksanaan Pembelajaran (RPP) dengan mengacu pada tindakan yang diterapkan dalam PTK dan berdasarkan apa yang telah terjadi pada siklus I.

(2) Menyiapkan alat-alat menarik yang dapat digunakan dalam permainan untuk membantu pembelajaran.

(3) Menyusun lembar observasi atau pengamatan pembelajaran.

b. Pelaksanaan Tindakan

Pada tahap pelaksanaan kegiatan yang akan dilakukan adalah melaksanakan proses pembelajaran di lapangan dengan langkah-langkah kegiatan antara lain:

(1) Menjelaskan kegiatan belajar mengajar keterampilan passing bola basket

(2) Melakukan pemanasan

(3) Memainkan permainan lempar tangkap bola

(4) Membentuk kelompok dalam proses pembelajaran

(5) Melakukan pembelajaran mengoper dan menerima bola menggunakan permainan.

(6) Menarik kesimpulan pembelajaran dan memberikan rekognisi atau penghargaan bagi siswa yang menampilkan keterampilan passing terbaik.

(7) Penilaian dilaksanakan selama proses pembelajaran berlangsung.

(8) Melakukan pendinginan.

(9) Berdoa dan membubarkan barisan. c. Observasi dan Interpretasi

Pengamatan dilakukan oleh guru sebagai peneliti kolaborasi saat proses pembelajaran berlangsung. Pengamatan dilakukan menggunakan lembar observasi dan lembar penilaian terhadap kemampuan gerak dasar keterampilan passing bola basket selama mengikuti proses KBM. Hasil observasi tersebut adalah :

1) Proses Tindakan

2) Pengaruh Tindakan

3) Kendala dalam Implementasi Tindakan

4) Identifikasi Penyebab Terkendala nya Tindakan

d. Refleksi Tindakan

Berdasarkan hasil observasi pada siklus II pertemuan pertama tersebut, peneliti melakukan analisis dan refleksi sebagai berikut:

(1) Pada pertemuan pertama siklus II, pencapaian indikator yang tercantum dalam RPP menunjukkan banyak sekali peningkatan. Hasil rekap nilai siswa yang nilainya sudah mencapai KKM bertambah 4 siswa dari siklus I yang belum tuntas.

(2) Pelaksanaan proses belajar mengajar telah sesuai dengan rencana yang telah dibuat dalam Rencana Pelaksanaan Pembelajaran (RPP).

(3) Siswa yang dirasa kurang berhasil pada pertemuan ini akan lebih difasilitasi.

(4) Peneliti harus lebih pintar mengatur waktu. Pada pertemuan ini, alokasi waktu banyak dihabiskan pada pembelajaran lempar tangkap 
dengan cara game karena siswa sangat menyenangi pembelajaran ini.

(5) Guru harus selalu memperhatikan siswa, karena masih ada siswa yang tidak serius waktu pembelajaran berlangsung.

(6) Guru sebagai peneliti memberikan reward bagi siswa yang dapat melakukan gerakan dengan benar meski hanya dengan pujian.

(7) Memberikan waktu untuk bisa bermain baik untuk lakilaki maupun perempuan.

\section{Siklus II Pertemuan 2}

a. Perencanaan Tindakan

Perencanaan tindakan, sebagai berikut:

1) Guru sebagai peneliti berkolaborasi membuat Rencana Pelaksanaan Pembelajaran berdasarkan (RPP) yang telah terjadi pada siklus I.

2) Menyiapkan dan melengkapi alat-alat menarik yang dapat digunakan dalam permainan untuk membantu pembelajaran.

3) Menyusun lembar observasi atau pengamatan pembelajaran.

b. Pelaksanaan Tindakan

Pada tahap pelaksanaan, kegiatan yang akan dilakukan adalah melaksanakan proses pembelajaran di lapangan dengan langkah-langkah kegiatan antara lain:
(1) Menjelaskan kegiatan belajar mengajar tentang keterampilan passing bola basket.

(2) Melakukan pemanasan.

(3) Memainkan permainan lempar tangkap bola dengan cara berpasangan dan beregu.

(4) Membentuk kelompok dalam proses pembelajaran.

(5) Melakukan pembelajaran mengoper dan menerima bola menggunakan permainan.

(6) Menarik kesimpulan pembelajaran dan memberikan rekognisi atau penghargaan bagi siswa yang dapat menampilkan keterampilan terbaik.

(7) Penilaian dilaksanakan selama proses pembelajaran berlangsung.

(8) Melakukan pendinginan dan follow up.

(9) Berdoa dan membubarkan barisan.

c. Observasi Tindakan

Pengamatan dilakukan oleh guru sebagai peneliti berkolaborasi saat proses pembelajaran. Pengamatan dilakukan menggunakan lembar observasi dan lembar penilaian terhadap kemampuan keterampilan passing bola basket selama mengikuti proses KBM. Hasil observasi tersebut adalah:

1) Proses Tindakan

2) Pengaruh Tindakan

3) Kendala dalam Implementasi Tindakan

4) Identifikasi Penyebab Terkendala nya Tindakan

d. Refleksi Tindakan Berdasarkan hasil observasi pada siklus II pertemuan kedua 
tersebut, peneliti melakukan analisis dan refleksi sebagai berikut:

1) Pelaksanaan proses belajar mengajar telah sesuai dengan rencana yang dibuat pada Rencana Pelaksanaan Pembelajaran (RPP) siklus II.

2) Model pembelajaran Contextual Teaching and Learning yang diterapkan oleh guru sebagai peneliti mampu mengatur kondisi lapangan sehingga proses belajar mengajar serta transfer materi dapat berlangsung lebih maksimal, serta penguatan materi yang dilakukan pada siklus II pertemuan kedua dapat terlaksana dengan baik.

3) Guru sebagai peneliti memberikan reward bagi siswa yang dapat melakukan gerakan keterampilan passing bola basket dengan benar.

4) Afektif siswa selama mengikuti proses belajar mengajar pada siklus II pertemuan kedua telah semakin baik, tetapi masih ada 2 siswa yang belum dapat mencapai nilai maksimal dikarenakan masih sulit untuk diatur. Pada saat melakukan permainan terkadang masih seenaknya sendiri.

5) Pemahaman materi yang telah dituangkan dalam pengerjaan soal sudah ada sedikit peningkatan dibanding siklus sebelumnya.

6) Kemampuan siswa dalam melakukan keterampilan passing bola basket meningkat dari $78,57 \%$ ketuntasan pada siklus I menjadi $92,86 \%$ pada akhir siklus II. Ini membuktikan bahwa target capaian ketuntasan sudah tercapai.

Dengan demikian baik secara ketuntasan belajar maupun ratarata hasil belajar keterampilan passing bola basket terjadi peningkatan yang sangat berarti, sehingga dapat disimpulkan bahwa penerapan model pembelajaran Contextual Teaching and Learning sangat efektif dalam meningkatkan hasil belajar keterampilan passing bola basket.

Tabel 5 Hasil Belajar Siklus II

\begin{tabular}{|c|c|c|c|}
\hline Responden & Nilai & Deskripsi & Ket \\
\hline 1 & 80 & $\begin{array}{l}\text { Mampu } \\
\text { melakukan } \\
\text { passing } \\
\text { dengan baik }\end{array}$ & Tuntas \\
\hline 2 & 80 & $\begin{array}{l}\text { Mampu } \\
\text { melakukan } \\
\text { passing } \\
\text { dengan baik }\end{array}$ & Tuntas \\
\hline 3 & 78 & $\begin{array}{l}\text { Baru } \\
\text { menguasai } \\
\text { posisi badan } \\
\text { dan sikap } \\
\text { tangan, } \\
\text { perkenaan } \\
\text { bola kurang } \\
\end{array}$ & Tuntas \\
\hline 4 & 90 & $\begin{array}{l}\text { Mahir dalam } \\
\text { melakukan } \\
\text { passing sesuai } \\
\text { teknik }\end{array}$ & Tuntas \\
\hline 5 & 85 & $\begin{array}{l}\text { Mahir dalam } \\
\text { melakukan } \\
\text { passing }\end{array}$ & Tuntas \\
\hline 6 & 80 & $\begin{array}{l}\text { Mampu } \\
\text { melakukan } \\
\text { passing } \\
\text { dengan baik }\end{array}$ & Tuntas \\
\hline 7 & 80 & $\begin{array}{l}\text { Mampu } \\
\text { melakukan } \\
\text { passing }\end{array}$ & Tuntas \\
\hline
\end{tabular}


Wawasan:

Jurnal Kediklatan Balai Diklat Keagamaan Jakarta

PISSN: 2548-9232; ${ }_{\mathrm{E}}$ ISSN: 2775-3573

Volume 2 Nomor 1 Tahun 2021: 49-63

\begin{tabular}{|c|c|c|c|}
\hline & & dengan baik & \\
\hline 8 & 83 & $\begin{array}{l}\text { Mampu } \\
\text { melakukan } \\
\text { passing sesuai } \\
\text { teknik yang } \\
\text { baik }\end{array}$ & Tuntas \\
\hline 9 & 80 & $\begin{array}{l}\text { Mampu } \\
\text { melakukan } \\
\text { passing } \\
\text { dengan baik }\end{array}$ & Tuntas \\
\hline 10 & 73 & $\begin{array}{l}\text { Baru } \\
\text { menguasai } \\
\text { posisi badan } \\
\text { dan sikap } \\
\text { tangan, } \\
\text { perkenaan } \\
\text { bola kurang }\end{array}$ & $\begin{array}{l}\text { Tidak } \\
\text { Tuntas }\end{array}$ \\
\hline 11 & 85 & $\begin{array}{l}\text { Mahir dalam } \\
\text { melakukan } \\
\text { passing }\end{array}$ & Tuntas \\
\hline 12 & 80 & $\begin{array}{l}\text { Mampu } \\
\text { melakukan } \\
\text { passing } \\
\text { dengan baik }\end{array}$ & Tuntas \\
\hline 13 & 78 & $\begin{array}{l}\text { Baru } \\
\text { menguasai } \\
\text { posisi badan } \\
\text { dan sikap } \\
\text { tangan, } \\
\text { perkenaan } \\
\text { bola kurang }\end{array}$ & Tuntas \\
\hline 14 & 80 & $\begin{array}{l}\text { Mampu } \\
\text { melakukan } \\
\text { passing } \\
\text { dengan baik }\end{array}$ & Tuntas \\
\hline 15 & 83 & $\begin{array}{l}\text { Mampu } \\
\text { melakukan } \\
\text { passing sesuai } \\
\text { teknik yang } \\
\text { baik }\end{array}$ & Tuntas \\
\hline 16 & 85 & $\begin{array}{l}\text { Mahir dalam } \\
\text { melakukan } \\
\text { passing }\end{array}$ & Tuntas \\
\hline 17 & 83 & $\begin{array}{l}\text { Mampu } \\
\text { melakukan } \\
\text { passing sesuai } \\
\text { teknik yang } \\
\text { baik }\end{array}$ & Tuntas \\
\hline 18 & 80 & $\begin{array}{l}\text { Mampu } \\
\text { melakukan } \\
\text { passing } \\
\text { dengan baik }\end{array}$ & Tuntas \\
\hline 19 & 85 & Mahir dalam & Tuntas \\
\hline
\end{tabular}

\begin{tabular}{|c|c|c|c|}
\hline & & $\begin{array}{l}\text { melakukan } \\
\text { passing }\end{array}$ & \\
\hline 20 & 80 & $\begin{array}{l}\text { Mampu } \\
\text { melakukan } \\
\text { passing } \\
\text { dengan baik }\end{array}$ & Tuntas \\
\hline 21 & 80 & $\begin{array}{l}\text { Mampu } \\
\text { melakukan } \\
\text { passing } \\
\text { dengan baik }\end{array}$ & Tuntas \\
\hline 22 & 73 & $\begin{array}{l}\text { Baru } \\
\text { menguasai } \\
\text { posisi badan } \\
\text { dan sikap } \\
\text { tangan, } \\
\text { perkenaan } \\
\text { bola kurang }\end{array}$ & $\begin{array}{c}\text { Tidak } \\
\text { Tuntas }\end{array}$ \\
\hline 23 & 80 & $\begin{array}{l}\text { Mampu } \\
\text { melakukan } \\
\text { passing } \\
\text { dengan baik }\end{array}$ & Tuntas \\
\hline 24 & 78 & $\begin{array}{l}\text { Baru } \\
\text { menguasai } \\
\text { posisi badan } \\
\text { dan sikap } \\
\text { tangan, } \\
\text { perkenaan } \\
\text { bola kurang } \\
\end{array}$ & Tuntas \\
\hline 25 & 80 & $\begin{array}{l}\text { Mampu } \\
\text { melakukan } \\
\text { passing } \\
\text { dengan baik }\end{array}$ & Tuntas \\
\hline 26 & 78 & $\begin{array}{l}\text { Baru } \\
\text { menguasai } \\
\text { posisi badan } \\
\text { dan sikap } \\
\text { tangan, } \\
\text { perkenaan } \\
\text { bola kurang }\end{array}$ & Tuntas \\
\hline 27 & 90 & $\begin{array}{l}\text { Mahir dalam } \\
\text { melakukan } \\
\text { passing sesuai } \\
\text { teknik }\end{array}$ & Tuntas \\
\hline 28 & 85 & $\begin{array}{l}\text { Mahir dalam } \\
\text { melakukan } \\
\text { passing }\end{array}$ & Tuntas \\
\hline Jumlah & 2272 & & \\
\hline Rata-rata & 81,14 & & \\
\hline *KKM: 75 & & & \\
\hline
\end{tabular}


Wawasan:

Jurnal Kediklatan Balai Diklat Keagamaan Jakarta PISSN: 2548-9232; ${ }_{\mathrm{E}}$ ISSN: 2775-3573

Volume 2 Nomor 1 Tahun 2021: 49-63

Berikut hasil kegiatan pembelajaran Siklus II dalam persentase ketuntasan minimal:

Tabel 6 Hasil Belajar Siswa dalam Keterampilan Passing Bola Basket Siklus II

\begin{tabular}{|c|c|c|c|}
\hline \multirow[t]{2}{*}{ Penilaian } & \multicolumn{2}{|c|}{ Kondisi Siklus II } & Ket \\
\hline & Persentase & $\begin{array}{c}\text { Jumlah } \\
\text { Siswa }\end{array}$ & \\
\hline Hasil & $92,86 \%$ & 26 & Tunta \\
\hline Belajar & & & $\mathrm{s}$ \\
\hline $\begin{array}{l}\text { Keterampil } \\
\text { an Passing } \\
\text { Bola Basket }\end{array}$ & $7,14 \%$ & 2 & $\begin{array}{c}\text { Belu } \\
\text { m } \\
\text { Tunta }\end{array}$ \\
\hline
\end{tabular}

\section{Perbandingan Hasil Tindakan Antar Siklus}

Hasil belajar keterampilan passing dari keadaan siswa pada pra siklus $67,86 \%$ mengalami peningkatan menjadi $78,57 \%$ pada siklus I dan pada siklus II kembali meningkat menjadi $92,86 \%$.

Tabel 7 Hasil Belajar Pra Suklus, Siklus I dan siklus II

\begin{tabular}{ccccc}
\hline $\begin{array}{c}\text { Respon } \\
\text { den }\end{array}$ & $\begin{array}{c}\text { Pra } \\
\text { Siklus } \\
\text { (Nilai) }\end{array}$ & $\begin{array}{c}\text { Siklus } \\
\text { I } \\
\text { (Nilai) }\end{array}$ & $\begin{array}{c}\text { Siklus } \\
\text { II } \\
\text { (Nilai) }\end{array}$ & Ket \\
\hline $\mathbf{1}$ & 75 & 78 & 80 & Tuntas \\
\hline $\mathbf{2}$ & 73 & 75 & 80 & Tuntas \\
\hline $\mathbf{3}$ & 70 & 73 & 78 & Tuntas \\
\hline $\mathbf{4}$ & 78 & 80 & 90 & Tuntas \\
\hline $\mathbf{5}$ & 78 & 85 & 85 & Tuntas \\
\hline $\mathbf{6}$ & 75 & 78 & 80 & Tuntas \\
\hline $\mathbf{7}$ & 73 & 75 & 80 & Tuntas \\
\hline $\mathbf{8}$ & 75 & 80 & 83 & Tuntas \\
\hline $\mathbf{9}$ & 75 & 78 & 80 & Tuntas \\
\hline $\mathbf{1 0}$ & 73 & 73 & 73 & Tuntas \\
\hline $\mathbf{1 1}$ & 78 & 83 & 85 & Tuntas \\
\hline & & & & \\
\hline & & & & \\
\hline
\end{tabular}

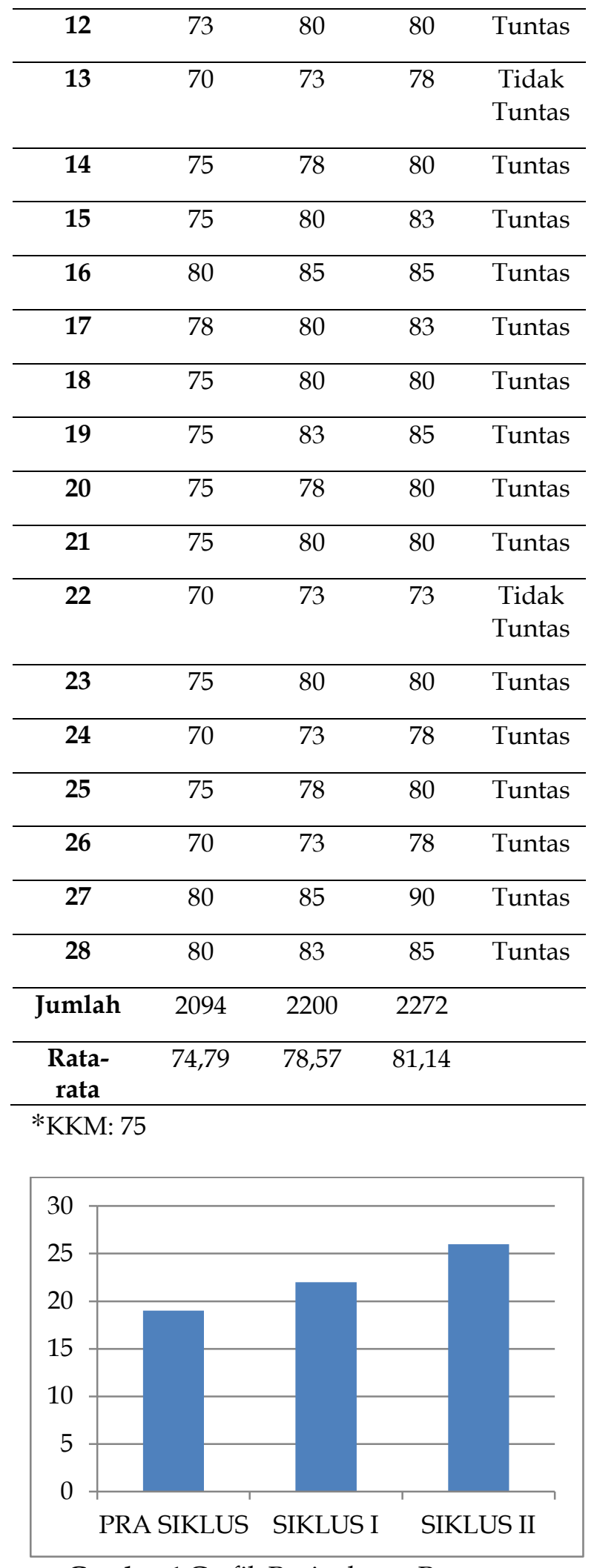

Gambar 1 Grafik Peningkatan Persentase Ketuntasan Hasil Belajar Keterampilan Passing Bola Basket 
Wawasan:

Jurnal Kediklatan Balai Diklat Keagamaan Jakarta PISSN: 2548-9232; ${ }_{\mathrm{E}}$ ISSN: 2775-3573

Volume 2 Nomor 1 Tahun 2021: 49-63

\section{KESIMPULAN}

Proses Penelitian Tindakan Kelas pada kelas IX G MTsN 1 Kota Serang Tahun Pelajaran 2015/2016 dilaksanakan dalam dua siklus dan berjalan dengan lancar. Dari hasil analisis yang diperoleh, penggunaan model pembelajaran Contextual Teaching and Learning dapat meningkatkan keterampilan passing bola basket dari pra siklus, siklus I dan siklus II. Kemampuan keterampilan passing pada pra siklus $67,86 \%$ atau 19 orang siswa yang diatas KKM maka pada siklus I meningkat menjadi $78,57 \%$ atau 22 orang siswa yang mencapai batas KKM. Pada siklus II terjadi peningkatan persentase kelulusan sebesar 92,86\% dengan 26 siswa berhasil mencapai batas KKM dari keseluruhan jumlah 28 siswa.

Guru Penjas Orkes hendaknya terus berusaha untuk meningkatkan kemampuannya dalam mengembangkan materi, menyampaikan materi, serta dalam mengelola kelas, sehingga kualitas pembelajaran yang dilakukannya dapat terus meningkat seiring dengan peningkatan kemampuan yang dimilikinya. Selain itu guru hendaknya mau membuka diri untuk menerima berbagai bentuk masukan, saran, dan kritikan agar dapat lebih memperbaiki kualitas mengajarnya.

\section{DAFTAR PUSTAKA}

Arikunto, S. Suharjono dan Supardi. (2010). Penelitian Tindakan Kelas. Jakarta: PT Bumi Aksara.

Djamarah, Syaiful Bahri. (2008). Psikologi Belaja Edisi 2. Jakarta: Rineka Cipta.

Harting, Rosma. (2010). Model Penelitian Tindakan Kelas. Yogyakarta: Teras.

Kristiyanto, Agus. (2010). Penelitian Tindakan Kelas (PTK); Dalam Pendidikan Jasmani $\mathcal{E}$ Kepelatihan Olahraga. Surakarta: UNS Press.

Lutan, R. dan Suherman, A. (2000). Supervisi Pendidikan Jasmani Konsep dan Praktek. Jakarta: Depdiknas.

Mulyana, H.E. (2009). Praktek Penelitian Tindakan Kelas. Bandung: PT Remaja Rosdakarya.

Nazir, Moh. (2005). Metode Penelitian, Bogor: Ghalia Indonesia. PB. PERBASI. (2004), Peraturan Resmi Bola Basket, Jakarta: PB. PERBASI.

Rusman. (2011). Model - Model Pembelajaran Mengembangkan Profesionalisme Guru, Jakarta: Rajawali Pers.

Wahyuni, Sri, dkk. (2010)). Pendidikan Jasmani, Olahraga, dan Kesehatan 2. Jakarta: Pusat Perbukuan, Kementerian Pendidikan Nasional.

Yuniartik, H., Hidayah, T., \& Nasuka, N. (2017). Evaluasi Pembelajaran Pendidikan Jasmani Olahraga dan Kesehatan di SLB C Se-Kota Yogyakarta. Journal of Physical Education and Sports, 6(2), 148-156. 